\title{
ISLAM AND THE WEST: FROM CLASH TO DIALOGUE
}

\author{
Bachar Bakour \\ International Islamic University Malaysia
}

\begin{abstract}
No doubt that the present fluctuating relation between Islam and the West is, and has always been, coloured by earlier encounters, (the spread of Islam, the Crusades, the Reconquista of Spain, the Inquisitions, to name a few). This article readdresses Islam-West relation by examining the fundamental underpinnings of the clash theory as delineated by Bernard Lewis in "The Roots of Muslim Rage" and Samuel Huntington in "The Clash of Civilizations." Though Lewis laid the foundation of civilizational conflict, it was Huntington who later fashioned and set the parameters of this conflict. The article also attempts to forge the idea of mutual understanding and dialogue by way of building bridges of scholarship, knowledge, respect and co-operation between people within this global village. To achieve this goal, the article highlights seven principles of the Islamic perspective of dialogue, drawing practical precedence from Islamic history, particularly from the Prophetic as well as the rightly-guided Caliphs' era.
\end{abstract}

Keywords: Clash, dialogue, Islam, West, civilisation, Lewis, Huntington.

\footnotetext{
* Corresponding author: bbakkour@yahoo.com eISSN 2636-9265 (C) Centre for Civilisational Dialogue
} 
O people, We created you from a male and a female, and made you into nations and tribes, so that you may come to know each other.

(The Qur'an, 49:13)

He who knows himself and other, will also recognize that East and West cannot be separated.

\section{Goethe}

(Clarke, 1997, 3)

Oh, East is East, and West is West, and never the twain shall meet. Till the Earth and Sky stand presently at God's great Judgement Seat.

\section{Kipling}

(Clarke, 1997, 3)

Gardens, like civilizations, can be described, analyzed and interpreted. But one thing is certain. It would be absurd to speak of $a$ "clash of gardens." It is equally absurd to speak of a "clash of civilizations."

\section{Jack Matlock}

(Matlock, 1999, 439)

\section{Introduction: Islam vs the West}

It may be argued that the notion of a difference does not appear as clearly as when it relates to the Islam/West dichotomy. The label 'Islam' brings to mind a set of long-established cultural and traditional beliefs and practices which are at odds with their Western counterparts. For centuries, until this present moment, Muslims, Christians and Jews have lived in proximity in many places, and have interacted with each other. The understanding and response of each group have been guided and even dominated primarily by its own religious and theological discourse, the shifting tides of 
political position. To some extent, it has also be influenced by historical circumstances, as well as day-to-day contact and experience.

This age-old fluctuating relationship created or helped to create a growing sense of unease and anxiety. The atmosphere of mutual suspicion, paving the way to the present, and somewhat persistent, antipathy between Islam and the West, has been coloured by earlier encounters. These encounters include the phenomenal spread of Islam, the Christian-initiated Crusades, the Reconquista of Spain, the Inquisitions, the Ottoman Empire and later encounters and incidents, such as the European colonialism of Muslim territories in the eighteenth and nineteenth centuries, the ArabIsraeli conflict, the Iranian Revolution and the economic threat of oil embargoes. Of these, it was the European colonialism that has had an unmistakable imprint on the minds of Muslims all over the world which, in turn, aggravated Muslim-Western relations at various levels. More dangerously, these unpleasant historical events, by way or another, were made to form the basis for the 'clash theory'.

With the traumatic event of $9 / 11$, the theory has gained wide currency in the elite circles, media outlets, as well as the populace. Now, it has been realized that there are no possibilities of peaceful co-existence between the inhabitants of these two geographical locations, for, to them, Islam is a synonym for fanaticism and terrorism, and incompatible in every aspect to the Western life model.

Is this Western perception of Islam credible and valid? Are Islam and the West on a collision course? Is the notion of difference, as some argued, bound to breed violence and hatred? Can people of different religious orientations live together peacefully and amicably? If yes, how can that be achieved?

It is worth mentioning, as will be shown in the following discussions, that the current mounting tension is partly due to a lack of sufficient and proper understanding of Islam in the West. This is partly due to the failure of Muslims, especially those living in foreign countries, to present their religion correctly and appropriately. Furthermore, Muslims are invited to move beyond stereotypes about the West and should set out on an intellectual journey to better understand and appreciate the real life, thoughts 
and ideals of Western nations. Such a journey would most certainly banish a considerable amount of negative images of the West. Subsequently, barriers of doubt and ignorance shall be removed with no hope of return, since a present accurate image has now replaced the ill-informed image of the past. For instance, one can consider the positive work in which various western institutions are engaged for human welfare in addition to impressive philanthropic programmes undertaken with the aid of the church. This situation no doubt comes under the umbrella of universal moral values, adherently shared by of all the faiths, notably monotheistic ones. Probably, this would endorse the durable validity of the famous Arabic proverb that says, 'Man is the enemy of that which he does not know.'

\section{The Clash Theory Tested}

The Western perception of Islam can be divided into two major attitudes (similarly applicable to Muslims' opinion of the West). The first attitude, which is less dominant, espouses an accommodating approach by arguing that Islam, besides being a sister religion, has a lot in common with Judaism and Christianity. It depicts Islam as a pacifist rational religion with a remarkable civilization that was formerly participated in the rise of the present-day scientific revolution of the West. Therefore, forging friendly and healthy relations with Muslims, as neighbours, is a pressing need and a necessary step for the "Dialogue of Civilizations." Foremost among the advocates of this stand is Pope John Paul II, Kofi Annan, the former UN Secretary-General, HRH Charles, the Prince of Wales, Nelson Mandela and Bishop Desmond Tutu of South Africa.

The second attitude, which is more fervent and prevalent, contends that Islam and Muslims, being violent, fanatical, despotic, sensual, aberrant, irrational and ignorant, present a dire threat to the diametrical opposite Western way of life culturally, politically, as well as demographically. As a result, the "Clash of Civilizations" is an inevitable encounter. For decades, both conflicting ideas had been in an oscillating position until 9/11 struck a deadly blow to the 'dialogue theory' to the advantage of its adversary.

With regret, a large number of Western think tanks, academics, writers, correspondents and commentators, especially 
after 9/11, have preferred to be on the side of this confrontational approach. Two figures, in particular, are held to be the primary architects of a long-running, fierce campaign against 'fundamentalist-militant Islam,' Bernard Lewis and Samuel Huntington.

\section{Bernard Lewis's "The Roots of Muslim Rage"}

Bernard Lewis of Princeton University is considered as one of the most influential academics on Islamic history and experts on the Middle East. For the most part, his rhetorical outpourings play a key role in widening the gulf between Islam and the West. Addicted to fulfilling the notion of civilizational conflict, Lewis views Christendom and Islam as civilisations that have been on a perpetual collision path since the advent of Islam. In a blatantly reductive manner, he informs the readers of a relationship that is, mostly and probably exclusively, dominated by 'a long series of attacks and counterattacks, jihads and crusades, conquests and reconquests.' It is of no surprise that Lewis was among the first who used the phrase 'clash of civilisations,' which later became the title of Samuel Huntington's infamous article.

"The Roots of Muslim Rage" appeared in the September 1990 issue of the Atlantic Monthly. The appearance of this article at this time cannot be a coincidence. It ought to be considered against the backdrop of the collapse of the Soviet Union, marking the end of the Cold War and defining and formulating a new era of world politics in general, and U.S foreign policy and strategic interests in particular.

The U.S siege mentality was in search of a new bogeyman to replace communism as the arch-enemy of Western civilisation. The perfect substitute seemed to have been 'the Islamic bloc', the ageold theological, geographical and political arch-rival (see Haddad, 1993), a Green Menace in place of a Red Menace. According to William Pfaff (Esposito, 1999, 1), 'There are a good many people who think that the war between communism and the West is about to be replaced by a war between the West and Mislims.'

Lewis's article provided a new strategy with an intellectual rationale, coupled with the moral vindication of an anticipated war against the Muslim world. In it, Lewis tried to explain the unjustified 
Muslim hostility to the USA/West or, shall we say, to the common Judeo-Christian heritage. To him, Islam and the Muslim societies, despite being mosaic rather than monolithic, are merely reduced to acts of rage, resentment, extremism, militancy, hatred, attacks and holy war. Even worse, the front cover of the article added conviction to the defective gloomy picture painted by Lewis; an illustration of a stereotypically bearded, turbaned, glaring Muslim, with the American flags in his bloodshot eyes.

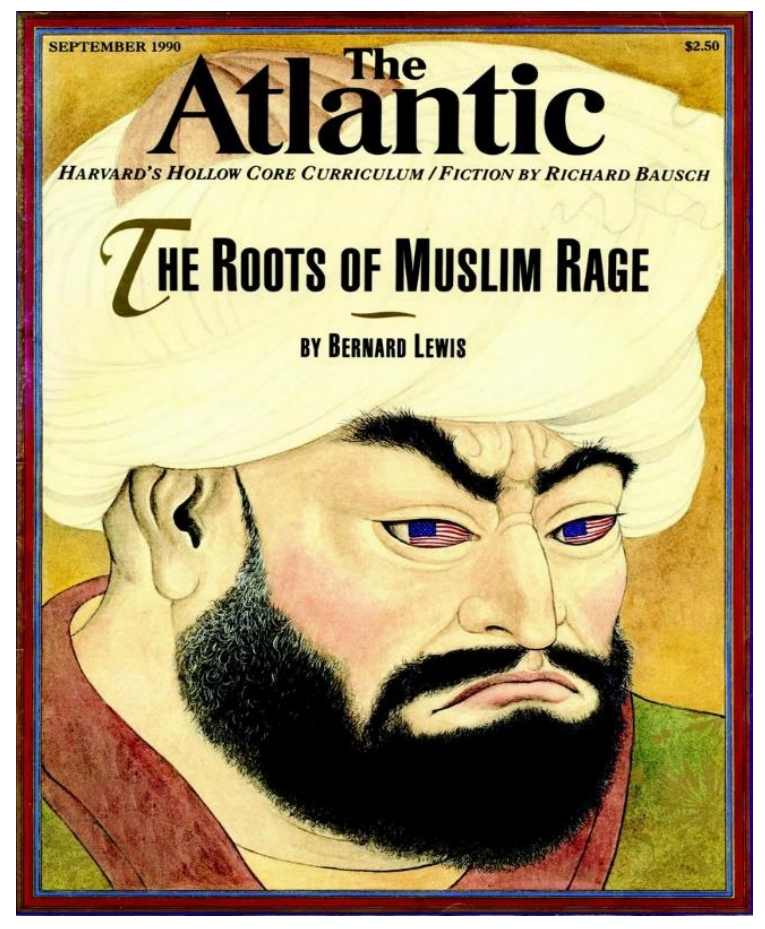

Figure 1. The front cover of Lewis's article. Reprinted from "the Roots of the Muslim Rage”, by B. Lewis, 1990, the Atlantic, September issue., Retrieved October 28, 2017, from https://www.theatlantic.com/magazine/toc/1990/09/.Copyright 1990 by the Atlantic Monthly Group. Reprinted with permission.

\section{Discussed ideas}


1- According to Lewis (1990), Jihad is a holy war in the path of God. He says, "The army is God's army, and the enemy is God's enemy. The duty of God's soldiers is to dispatch God's enemies as quickly as possible to the place where God will chastise them -- that is to say, the afterlife". (Lewis, 1990).

It should be made very clear that the notion of the 'holy war', a Christian term, is completely alien to the Islamic tradition. Jihad is either legally justified or not, legitimate or otherwise. The very idea of holiness is dismissed from the minds of both medieval and modern Muslim scholars. Unlike 'war', be it holy or not, Jihad with its broader concept can be categorized into three categories: jihad al-da 'wah, namely, to endeavour various kinds of hardship to spread the Message of God; jihad al-nafs, to lead a life based on the instructions of Islam; and 'fighting jihad'. The third kind was legalised shortly after the Prophet (PBUH) settled in Madinah. (See al-Buti, 1978: 75). However, 'fighting' is governed and restricted by various conditions and rules which have been absent, theoretically and practically, in the so-called a 'holy war.'

On the other hand, Muslim troops, God's army, was portrayed by Lewis as bloodthirsty people whose messianic mission is to kill and slaughter God's enemy. The mission is to send them as soon as possible to their Lord where eternal damnation is awaiting them. Nevertheless, it is worth to compare this stereotyped image with the following:

- On many occasions, in peace and war, the Prophet Muhammad (PBUH) demonstrated boundless forgiveness and mercy towards his enemy, like the general amnesty (8 A.H) he granted to the people of Makkah, his fierce enemy. (see examples in Bakkour, 2010, 26-28).

- The Prophet (PBUH) says, "O people, do not wish to encounter with the enemy (in the battle) and ask God to save you (from calamities), but if you should face the enemy, then be patient and know that Paradise is under the shades of the swords." (alBukhārī, 1987, no. 2922; al-Qushayrī, n.d., no.1742).

- The Prophet (PBUH), and the rightly-guided caliphs, repeatedly made clear the prohibition of killing civilians or noncombatants (like children, women, the elderly, monks, and priests). (Ibn al-Altheer, 1969, no. 1080; 1082). 
- Furthermore, when the enemy ceases belligerence and seeks peace, Muslims have to respond positively. (The Qur'ān, 8: 61).

2- To prove the militancy of Islam and Muslims, Lewis reminded his readers about the Medieval Islamic concept of the Abode of Islam, and the Abode of Unbelief or of War. (1990). Lewis, like many other Western writers, fails to understand or present this dichotomous concept within its historical context. This dual worldview, not being part of the Islamic tenets, is derived neither from the Qur'ān nor from Prophetic tradition.

This is the opinion of eminent Muslim modern jurists, such as Muhammad Abu Zahrah, Abd al-Wahhab Khallaf as well as Wahbah al-Zyhayli. (al-Zyhayli, 1983, 193. see a different opinion in al-Qaradāwī, 2009, 2: 882-886). Instead, it was formulated by classical jurists during the medieval period as a product of historical circumstances and existing norms of international relations of the time. (Abou El Fadl, 2005, 223-226).

By this classification, jurists could provide a blueprint for essential features of Muslim territory versus those of non-Muslim territory, and establish legal formulas for Muslims living outside the Muslim world.

On the other hand, there are also other unmentioned divisions in Lewis's assumption: dar al-Salam (Abode of Peace); dar al'ahd or dar al-Sulh (House of agreement), "The notion of the house of war... has been affected by historical changes. With the fragmentation of the Muslim world into a multitude of states and the progressive decline of their power, dar al-harb has been divested of its significance. Moreover, the inclusion of Muslim countries in the modern international juridical order implies the renunciation of such a concept." (Djalili, 1995, 1: 337).

Muslim intellectuals, like Khaled Abou El Fadl (2005, 228) and Tariq Ramadan $(2005,125-127)$ argued that according to some Medieval jurists, ${ }^{i}$ the abode of Islam is where justice exists, or where Muslims enjoy safety and peace. This is exactly what we are currently witnessing. Generally, Muslims are living a life of calmness and security in Western countries considerably more than in their own Muslim countries. 
3- As remarked above, Lewis viewed Christendom and Islam as conflicting civilisations. This hostile relation has been dominated by "a long series of attacks and counterattacks, jihads and crusades, conquests and reconquests." (Lewis, 1990). He wondered why America, all of a sudden, became the chief enemy of Muslims. (Lewis, 1990).

Commenting on this, John Esposito argued:

Islam and Muslims are here portrayed as instigators and protagonists in fourteen centuries of warfare. Islam is the aggressor. Islam and the acts of Muslims are held responsible for attacks, jihad and conquests, whereas the west is described as defensive, responding with counterattacks, crusades, and reconquests. Despite the claim of fourteen continuous centuries of confrontation, the reader is informed that 'suddenly' America has become the archenemy, evil, personified, and so forth. If the contemporary threat is 'sudden', then the reader will logically conclude that Muslims have a historical propensity to violence against and hatred for the West, or else, the Muslims are emotional, irrational, and prone to war. $(1999,221)$.

Concerning the sweeping anti-Americanism in the Muslim World, it should be remarked that this hostility, which is basically directed to the administration rather than the people, is by no means exclusive to Muslims. Arab, Eastern and some Western nations are to be included too. Furthermore, this resentment is seen as a normal response to decades of the U.S ill-conceived and insensitive foreign policies and military interventions in numerous spots in the world.

William Blum supported this argument by claiming that, "From 1945 to the end of the century, the United States attempted to overthrow more than 40 foreign governments and to crush more than 30 populist-nationalist movements struggling against intolerable regimes. In the process, the US caused the end of life for several million people and condemned many millions more to a life of agony and despair." $(2000,21)$. One example of such manoeuvre was the internationally-condemned, ill-justified and immoral American-led war on Iraq with all its attendant costs (Abu Ghraib scandal, Guantanamo Bay, an untold number of casualties, the 
horrid denigration of Muslim sacred symbols, missionary and evangelical activities) dragging American professed civility, reputation and culture in the dirt. ${ }^{\text {ii }}$

4- In attempting to uncover and pinpointing the underlying cause for the bloody war between Muslims and non-Muslims in places such as Ethiopian Eritrea, Indian Kashmir, Chinese Sinkiang, and Yugoslav Kosovo, Lewis, a prominent political commentator, argued that it is totally unacceptable and even blasphemous for believers to be ruled by non-believers because allowing this will result in the abrogation of Sharia law and moral decadence in Muslim society. (Lewis, 1990). According to Lewis, it is only the triumphant disbelief that leads to violent conflicts in the countries mentioned above. Again, Lewis shows a remarkable failure in grasping an accurate perception of the situation in question.

I must refer here to Charles Glass, a writer, journalist, broadcaster, who had written about the conflict in the Middle East, Africa and Europe for over four decades.

At the time he was covering the war in Eritrea, Glass pointed out that the guerrillas did not refer to religion as the reason for fighting. (2004). Instead the majority of Eritreans, Muslims and non-Muslims initial intention was to bring down their Ethiopian emperor, Haile Selassie, who had been awarded Eritrea by the Allies at the end of the Second World War (Glass, 2004). As for Yugoslav Kosovo and the Sinkiang's struggle, Islam was never the reason for the wars to occur. (Glass, 2004).

More importantly, in contrary to Lewis's assumption that it is blasphemous for believers to be ruled by non-believers, there are many religious Muslims and liberals who have shown preference to live under the rule of non-believers in Western countries. Based on the Arab Human Development Report, which provided a detailed account and scathing assessment of the economic, demographic, social and political conditions in the Arab and Muslim world, one can deduce that this mass migration is fundamentally driven by intolerable grievances: poverty, oppression, dictator leaders, high rates of unemployment, deteriorating living standards, and the like. (see Baroudi, 2004, 132141). Ironically, Christians and Jews in the past had sought the 
refuge and protection of the Ottoman Empire, where they received fair treatment and lived a prosperous life. (Shaw, 1991, 30-31).

5- Lewis also asserted that "The true faith, based on God's final revelation, must be protected from insult and abuse; other faiths, being either false or incomplete, have no right to any such protection." (1990). The following historical documents and accounts sufficient to prove the fallacy of Lewis's argument:

- After he moved to Medina, the Prophet (PBUH) signed a treaty with the Jews. This document defined the status of the Jews and their relations with the Muslim State in Medina. (The document is available in Guillaume, 1990, 231233; Salahi, 2002, 239-242; and Bashier, 1990, 104-108). Another document was drawn up with the Christian people of Najran, which gave protection to their lives, possessions and churches. (Salahi, 2002, 751).

- There are validated hadith that guaranteed the safety and security to dhimmī and $M u$ ' $a \bar{h} i d$ who were accorded legal protection by the Muslim state. (See al-Qaradāwī, 1994, 338).

Lewis's article revealed inaccuracy and acute ignorance about the actual reality of Islam and Muslim societies. In Edward Said's words, Lewis's article is "a crude polemic devoid of historical truth, rational argument, or human wisdom." (1997).

\section{Samuel Huntington's "The Clash of Civilizations"}

Samuel Huntington, an Eaton Professor of the Science of Government at Harvard University, is an American political scientist who wrote extensively about international relations. Similar to Lewis, Huntington had the privilege of influencing policymakers with his writings that had a wide readership. Huntington 'was the leading advocate of the US war in Vietnam and a vigorous proponent of massive bombardment of the countryside.' (Lockman, 2004, 233).

Though Lewis laid the foundation of civilisational conflict, it was Huntington who later fashioned and set the parameters of this conflict with a powerful grip on thoughts and debates that influenced numerous policymakers, academics, diplomats as well as journalists. 
In the issue of Foreign Affairs published in summer 1993, Huntington wrote an article entitled 'The Clash of Civilizations?' Delineating the post-Cold War discourse of International Relations in general and U.S foreign policy in particular and setting the stage for a heated debate about Islam-West relationship. The article generated more discussion during the three years than anything the journal had published since the Second World War. In 1996, Huntington further explored his thesis in 'The Clash of Civilizations and the Remaking of World Order,' (New York: Simon \& Schuster) with the question mark omitted.

Huntington' explained the civilisational conflict paradigm as follows:

It is my hypothesis that the fundamental source of conflict in this new world will not be primarily ideological or primarily economic. The great divisions among humankind and the dominating source of conflict will be cultural. Nation states will remain the most powerful actors in world affairs, but the principal conflicts of global politics will occur between nations and groups of different civilizations. The clash of civilizations will dominate global politics. The fault lines between civilizations will be battle lines of the future. $(1993,22)$.

According to Huntington, the world contains seven or eight distinct civilisations: Western, Confucian, Japanese, Islamic, Hindu, Slavic-Orthodox, Latin American and possibly African civilisations. (1993, 25). He asserted that the fundamental differences between these civilisations, stemmed from divergent cultural, social and religious values which will eventually be the primary source of a global turmoil in the future. Previously, conflicts between states occurred due to military, economic, or strategic interests. Similarly, in the post-Cold War era, the conflict will find expression in the cultural or civilizational setting. "The people of different civilizations, " Huntington claimed, "have different views on the relations between God and man, the individual and the group, the citizen and the state, parents and children, husband and wife, as well as differing views of the relative importance of rights and responsibilities, liberty and authority, equality and hierarchy. These 
differences are the product of centuries". (1993, 25) Huntington (1996) made a refuted allegation that among these civilisations, the most threatening and violence-generating is the Islamic civilisation.

By casting Muslims as innately violent, Huntington further added that "the relations between Muslims and peoples of other civilisations - Catholic, Protestant, Orthodox, Hindu, Chinese, Buddhist, Jewish, have been generally antagonistic... wherever one looks along the perimeter of Islam, Muslims have problems living peacefully with their Neighbors." (1996, 256).

To prove his claim, Huntington cites Ted Gurr's quantitative studies on ethnopolitical conflicts in the early 1990s and, as a result, asserted his claims that "Muslims were engaged in more intergroup violence than were non-Muslims, and two-thirds to three-quarters of intercivilizational wars were between Muslims and non-Muslims." (1996, 257-258). Naturally, what flowed from is this that "Islam's borders are bloody, and so are its innards." (Huntington, 1996, 258). Inspired and even instigated by Bernard Lewis, Huntington further linked the current antipathy between Islam and the West with a centuries-old antagonistic relation. (See Huntington, 1993, 31; 1996, 209).

To give credence to his argument, Huntington identified five factors that fueled the conflict between Islam and the West.

First, the Muslim population growth has generated large numbers of unemployed and disaffected young people who become recruits to Islamist causes, exert pressure on neighboring societies, and migrate to the West. Second, the Islamic Resurgence has given Muslims renewed confidence in the distinctive character and worth of their civilization and values compared to those of the West. Third, the West's simultaneous efforts to universalize its values and institutions, to maintain its military and economic superiority, and to intervene in conflicts in the Muslim world generate intense resentment among Muslims. Fourth, the collapse of communism removed a common enemy of the West and Islam and left each the perceived major threat to the other. Fifth, the increasing contact between and intermingling of Muslims and Westerners stimulate in each a new sense of their own 
identity and how it differs from that of the other. (1996, 211).

\section{Discussion}

Huntington's damaging accusations of Islam, are primarily driven by his outdated monolithic conception of the Muslim society. He failed to engage in an impartial examination of the profound diversity and different expressed modalities (cultural, political, and social), that exist among Muslim countries. As history had proven, Muslims, like any other nations in the world, have different, sometimes competing and even clashing national interests, identities and tendencies, as well as markedly contrasting political affinities. The Iran-Iraq War and the Gulf-War are a perfect example of these differences.

Some Muslim countries such as Saudi Arabia, Egypt, Pakistan, Jordan and Indonesia have been staunch allies of the USA for years (see Robert Chase et al., 1996). Even Iran, a de facto political opponent of the United States, would be considered an ally when other interests are involved. The Irangate affair and the Iranian support of the United States of America when the latter invaded Afghanistan in 2001 were prime examples. Taking this into account, the oft-repeated fears of the alleged Pan-Islam or Pan-Arab as a global threat to the West are unfounded. (see the extensive discussion in Esposito, 1999, 222-226; and Halliday, 2002, 121 124). In actuality, it was the national interest and political expediency rather than morals, ethical commitments or religion that were the primary determinants in the formulation of foreign policy.

On the other hand, Muslims' perceptions of the West and its social and cultural norms varied widely. While some Westernoriented Muslims, be intellectuals or lay people, staunchly advocate an overall Western model life, others including traditionalists or conservatives, call for purely Islamic-based standards and ideas with abhorrence to everything Western. A third party, on the other hand, stakes a middle ground.

Instead of pointlessly finding ancient roots to the current conflicts between Muslims and the West, Huntington should have insisted on establishing the actual causes that had added fuel to the 
flame, such as the United States administrations's double standard policies; its partiality and unlimited support to the State of Israel. One could argue that in a book with a damaging prediction of an embedding clash between Muslims and the West, Israel was barely mentioned. Other causes included the unwarranted war on Iraq, the American espousal of the fiercely repressive and authoritarian Arab regimes, constantly targeting Islam and Muslims (the slaughter and torture of Bosnian Muslims by Serbians, the persecution of Kashmiris and the Hindu savagery against Muslims in India). These terrible incidents, despite playing a prime role in the present-day conflict between the Muslims and the West, have been entirely overlooked by Huntington's rhetoric.

One needs to keep in mind that ethnic conflicts Huntington cited such as in Rwanda, the Caucasus and former Yugoslavia, had absolutely nothing to do with a 'clash of civilisations' and everything to do with a 'clash of interests' or a 'clash of power,' and the like. In a seminal work that methodically examined the supposed conflicts of civilisational pertaining to the borders of Muslim nations, Huntington's theory can be seriously challenged. Case studies from a variety of countries, like Bosnia, Afghanistan, Ethiopia, Chechnya, Sudan, Pakistan, Nigeria needed to be reinvestigated and reframed with accuracy.

In a chapter entitled 'Philippines- "Civilizational" or Colonial Border,' Ben Reid claimed that instead of being caused by civilisational concerns, "the conflict must be understood by examining the shared legacies of colonialism, the dynamics of poverty and political exclusion as well as the military dependence of the Philippine elite on the US and how both of these actors desire territorial integrity and access to Mindanao's resources". (2009, 100).

In a similar vein, far from being the product of ethnic hatred or centuries-old conflicts, Svein Monnesland (2009, 220) considered the war in Bosnia as a result of the interference of outside forces. He referred to two facts: the Bosnian Muslims were liberals who were free from the intrusion of extremist ideas, and due to half a century of communist rule with a secularizing process, a whole generation was strongly secularized when the war broke out. (Svein, 2009, 219). 
Further, throwing light on the nature of the relationship between Muslims and Christians in the Balkans, Svein aptly stressed that:

In the Balkans, religion and nationality are closely interwoven. However, the conflicts in the Balkans in our times have not been exclusively between Christians and Muslims. The war in Croatia was between Catholics and Orthodox, and we have even seen deep conflicts between Orthodox brethren in Montenegro, i.e. even within the same state. Also between other Orthodox groups, there have been conflicts, for example between Macedonians, Serbs and Bulgarians. An indication that the religious split between Muslims and Christians does not in itself lead to conflicts can be found in the tolerant situation among Albanians. Of all the Albanians in the Balkans, about 70 percent are Muslims, about 20 percent Orthodox, and about 10 percent Catholics, but religion has never been a source of tension or conflict. Nor has been possible to neighbour states to use this split to achieve political goals. (2009, 219).

The above mentioned intra-Christian war, in addition to World War I, World War II, clearly suggested that, contrary to Huntington's claims, all civilisations and not merely the Muslims' are subject to many internal cultural, ideological conflicts and divisions.

In an attempt to prove that the idea of 'Islam's bloody borders' is a false conviction, I never negate the existing violence and extremism exercised by some 'brainwashed or misguided' disaffected Muslim groups and pockets across the world. Unfortunately, by their attention-seeking acts, they have overshadowed and obscured the reality of the pacifist, moderate and tolerant Islam and instead reinforced its already negative portrayal by the West. There is an urgency to thoroughly examine the ulterior motives that instigated such violent acts, and there must be a strong political will to tackle them, as no human being is deemed extremist or violent merely based on their faith. 
The tendency to judge the actions of a few to represent the majority, as shown by Huntington and Lewis, is fundamentally and grossly unfair. In any case, Islam is not the only religion that has been hijacked by fanatical groups. All religions, at one time or another, have been manipulated by a minority of its believers to inspire intolerance and violence.

The Jewish Defense League (JDL), an American urban terrorist organization, according to FBI reports, is the second most violent group in the United States (Haddad, 2000, 25). Gush Emunim, an Israeli movement with fanatic religious-chauvinist stance, IRA terrorists in Britain, Bharata Janatra Party (BJP) in India, Aum Shinrikyo, Buddhists; Ku Klux Klan (KKK), a terrorist organization in the USA; Baruch Goldstein and the massacre of many Palestinians while praying, Timothy Mcveigh and the Oklahoma City bombing, Reverend Michael Bray and the bombing of abortion clinics, the conflict between the Catholics and the Protestants in Northern Ireland were just a few examples of terrorist violence committed by others who had no link to Islamic teachings. It is unfair to pin the blame on Christianity, Judaism, Hinduism or Buddhism just because of the heinous crimes committed by individual terrorists and fringes who cloaked themselves in the mantle of religion.

\section{Pillars of Dialogue: The Islamic Perspective}

Muslims are encouraged to have constant positive engagements with their fellow human beings from various cultural and religious groups. For this purpose, Islam has set a number of principles which all Muslims, men and women, elite and laypeople, should follow and act upon.

First: Natural diversity is sacrosanct.

"If your Lord had willed, He would have made all mankind one single nation, but He willed it otherwise, and so they continue to differ." (The Qur'an, 11:118) Elsewhere, one reads "Had God so willed, He could have made you all one community." (The Qur'an, 5: 48) And, "O people, We created you from a male and a female, and made you into nations and tribes, so that you may come to know each other." (The Qur'an, 49:13). 
As these verses indicate that God had created human beings with a whole range of different beliefs, languages, customs, interests, as well as various intellectual abilities for ta 'āruf (getting to know one another). This $t a$ 'a $r u f$ is the Islam's call for embracing diversity with respect and understanding.

In this regard, the Prophet Muhammad (PBUH) was the finest role model. Once a funeral procession passed by him and as a gesture of respect, he rose. Thereupon, someone remarked, ' $O$ Messenger of God, it is a funeral of a Jew.' He replied: 'Is it not a soul?' (al-Bukhārī, 1987, no. 1312). Apart from that, it was reliably narrated that when the Prophet (PBUH) passed away, his armour was mortgaged to a Jew for thirty Sa's ${ }^{\text {iii }}$ of barley. (al-Bukhārī, 1987, no. 2916). The Prophet could have borrowed or even taken whatever he wanted with no repayment, from his loving Companions, who were ready to sacrifice their lives and children for his sake. By doing so, the Prophet was sending a message to his nation never disdain to deal with those who are different.

Furthermore, it was mentioned earlier that after he immigrated to Medina, the Prophet (PBUH) signed several documents with the Jews, Christians as well as Magians to safeguard their rights and clearly define their duties (Guillaume, 1990, 231-233; Salahi, 2002, 239-242, 751; and Bashier, 1990, 104-108).

Second: The freedom of belief.

"There must be no coercion in matters of faith." (The Qur'an, 2: 256).

Islam sees faith as a matter of conviction. It never seeks converts by means of compulsion. Instead, it addresses the human mind, intellect and human common sense. The freedom of belief, the most basic right, implies the freedom of expression and thought is highly regarded in Islam.

The mission of dā'iyah (caller to Islam) is to show people the straight path, make them aware of faith and belief, and remove from their mind any misconception about Islam. After that, it is the peoples' choices to make based on their freedom to decide. The reason is that embracing Islam would be entirely meaningless if people do not adopt it with a firmly-held belief coming from the sincerity of their hearts. This was illustrated by the early Muslims in Makkah. Since declaring their new faith, these pioneering Muslims 
were brutally tortured and had undergone intense physical and psychological pressures. The disbelievers hoped that such sufferings would make the Muslims renounce their belief. However, the renouncing of the Islamic faith did not happen. It was essentially the believers' strong conviction in their faith that inspired their steadfastness and willpower.

Some researchers, nevertheless, argued that verse (The Qur'an, 2: 256) had been abrogated, and the Prophet (PBUH) compelled followers of other faiths to accept Islam. On the one hand, this verse is subject to abrogation, because it relates to the freedom of belief, and opinion. Moreover, this long-lasting principle can never be repealed. (Bakkour, 2011, 18). On the other hand, there are verses in the Qur'an asserting 'Had your Lord so willed, all people on earth. Do you, then, try to compel people to believe?' (The Qur'an, 10:99), And, 'Say (O Muhammad): "This is the truth from your Lord. Let him who wills, believe in it, and let him who wills, reject it"' (The Qur'an, 18:29). (See Bakkour, 2011, 18).

Historically speaking, the Prophet (PBUH) never forced others, Arabs and non-Arabs, to embrace Islam. He launched a war against the oppressors who fought him, prevented him from propagating God's message and those who persecuted and expelled his followers. The Prophet (PBUH) used to address himself peacefully and convincingly, and never resorted to violent approaches or coercive conversions. (Bakkour, 2011, 18-20).

The overwhelming majority of scholars held the opinion that 'fighting-jihād' comes after conducting jihād al-da 'wah. Therefore, the former should not come into action unless a circumstance entails it, like medicine to which one resorts when necessary. This legal opinion is based on hadith reports directing Muslims to adopt this path of action. (See al-Buti, 1978, 15-18; al-Zuhaylī, 1983, 640).

Third: Diversity leads to mutual knowledge and constructive exchange.

In this context, the Qur'an says, "O people, We created you from male and female, and made you into nations and tribes, so that you may come to know each other." (The Qur'an, 49:13).

Despite the well-known periods of military confrontations, various religions and cultures borrowed from the rich intellectual heritage of each other by exchanging ideas and principles. ${ }^{\text {iv For }}$ example, as a sign of the impact of Arab and Muslim scholarships, 
many Arabic words were introduced in European languages, such as alchemy, alcohol, algebra. Al-Andalus (Muslim Spain), for example, was 'a cultural transplant on European soil and a natural bridge between East and West.' (Ansari \& Esposito, 2001, 53).

Far from being an exclusivist religion, Islam did not lose the sight of recognising the rich and valuable heritage of the 'others'. Islamic civilisation is the sphere in which acts of acknowledgement, preservation, and translation of scholarly works of other civilisations (Hellenistic, Persian, Indian) are conspicuously and abundantly existed.

In this respect, the 'Elephant Clock,' by the celebrated Muslim mechanical engineer Al-Jazari (1136-1206), is par-excellence. This spectacular clock incorporates elements from many cultures, representing the different cultural and scientific traditions which combined and flowed through the Muslim world. The clock's base is an elephant, representing India; inside the elephant, the waterdriven works of the clock derived from ancient Greece. A Chinese dragon swings down from the top of the clock to mark the hours. At the top is a phoenix, representing ancient Egypt. Sitting astride the elephant and inside the framework of the clock are automata, or puppets, wearing Arab turbans. (Higham, \& Ryan, 2010). 


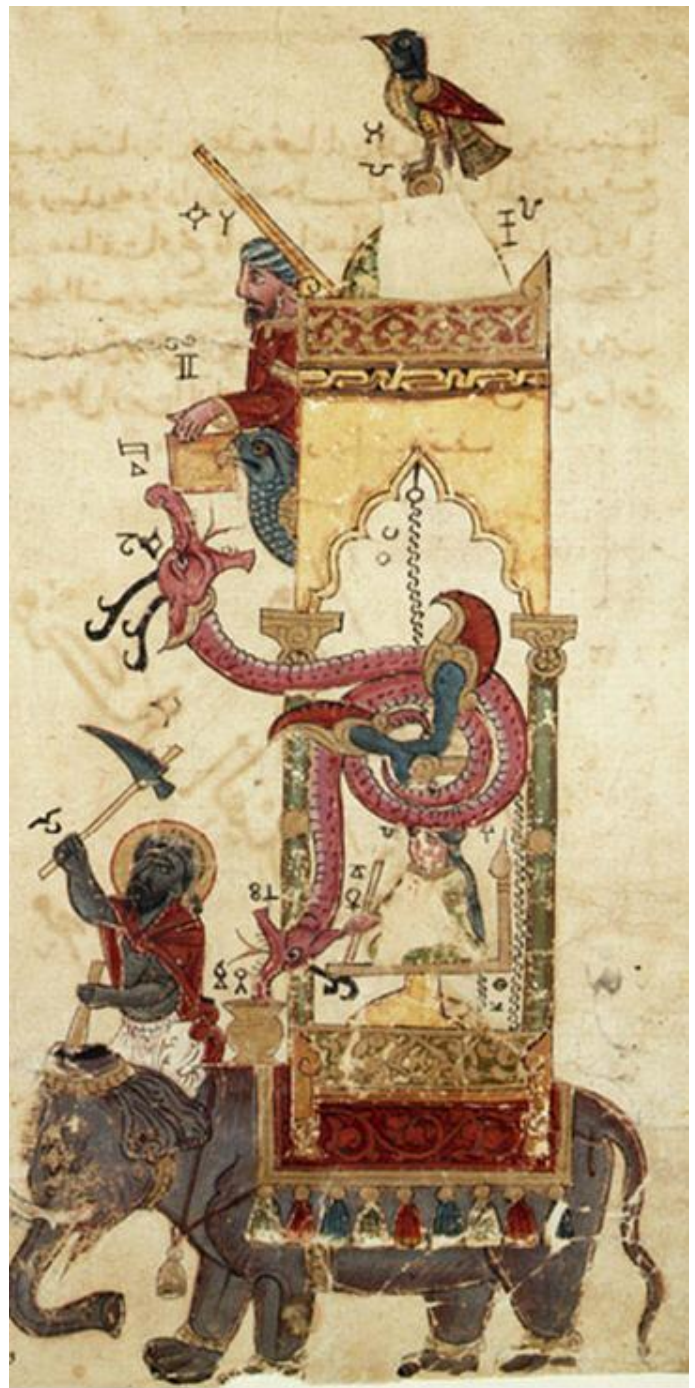

Figure 2. Drawing of al-Jazari's "Elephant Clock." Reprinted from "800 Years Later: In Memory of Al-Jazari, A Genius Mechanical Engineer”, by S. Al-Hassani, n.d., Muslim Heritage., Retrieved October 28, 2017. http://www.muslimheritage.com/article/800years-later-memory-al-jazari-genius-mechanical-engineer. Copyright by Foundation for Science Technology and Civilisation. Reprinted with permission. 
Professor Salim al-Hassani, the chairman of the Foundation for Science, Technology, and Civilization, holds an interactive $\mathbf{1 0 0 1}$ Inventions exhibition at the Science Museum in London. One day, a prominent British politician, upon visiting the exhibition, told alHassani that holding such permanent exhibition about exceptional scientific and technological advancements made by Muslims is a brilliant idea. The reason was the majority of young British Muslims have been experiencing inferiority complex, mainly because of the unbalanced depiction of Islam by the media that is deliberately underestimating the scientific and scholarly accomplishment of Islam. ${ }^{v}$ Therefore, by presenting shining scientific evidence of Muslims' achievements to the western community, Muslims, whether in the UK or elsewhere, can take pride in the success of the Muslim civilisations and people.

Fourth: Targeting religious symbols is strictly prohibited.

One is entirely free to adopt one's method of worship. This freedom, however, must not be contaminated by lowering the religious symbols and sacred places of others. As regards this, the Qur'an states, "And do not insult those whom they worship besides God, lest they insult God wrongfully without knowledge." (The Qur'an, 6:108).

The verse tells the believer not to get engaged in what is useless and counterproductive. Abusing unbelievers' deities will not put those unbelievers on the course of guidance. Instead, this action will only add to their obstinacy. As long as deference and respect to religious symbols failed to be recognised, there is no hope of creating a bridge-building platform of understanding. Commenting on the 2006 outrageous, Danish cartoons depicting the Prophet Muhammad (PBUH) in a derogatory manner, Professor John Esposito writo,

What we are witnessing today has little to do with Western democratic values and everything to do with a European media that reflects and plays to an increasingly xenophobic and Islamophobic society. Cartoons defaming the Prophet and Islam by equating them with terrorism are inflammatory. They reinforce Muslim grievances, humiliation and social marginalization and drive a wedge 
between the West and moderate Muslims, unwittingly playing directly into the hands of extremists. (2006).

Others, however, think that such insult is a kind of freedom and cited the Rushdie Affair ${ }^{\mathrm{vi}}$ as an example of Muslims' intolerance of liberal ideas and free thought. Several opinions about the matter included:

- The 1988 novel Satanic Verses vii by British Indian author Salman Rushdie, abused Prophet Muhammad (PBUH), his companions, slandered his wives, and, more dangerously, suggested that the Qur'an had been influenced and manipulated by Satan. No wonder, Muslims all over the World became profoundly wounded and violently shocked by the novel's offending passages. Riots were everywhere, in addition to the book burning that took place in many parts of the world.

- To put it in the right context, it should be made categorically clear it is not the freedom of thoughts and of expressions that distressed and insulted Muslims. It was rather the sheer slander and offensive attack on the most sacred Muslim symbol. Rushdie's novel has nothing to do with any form of freedom but everything to do with defamation and slander. A considerable number of Western commentators and writers, while espousing the notion of freedom of expression, laid particular emphasis on placing limits on it, otherwise it is the freedom of jungle. (Ahsan \& Kidwai, 1993, 39, 95-129). Moreover, it is because of these necessary restrictions and limitations, scores of offensive books were justifiably banned, withdrawn, or even burned. Other items had unjustifiably become victims of the same fate. (Ahsan \& Kidwai, 1993, 40, 163, 167).

-Islam is anything but suppressing the freedom of expression and opinion. Had this been true, the original and inspiring story of the Satanic Verses would have been erased from the early books of Islamic history. In a similar vein, the Qur'ān, in a number of occasions, has recorded the discourse and adopted views of dissenting voices and then refuted them by exposing their errors.

Historically speaking, when the Kharijites, meaning 'mutineers' or 'secessionists', broke away from the mainstream Muslims, with very extreme views and fanatical inclinations, Alī Ibn Abī Tâlib, the Prophet's cousin and the fourth caliph, held negotiations with them before fighting them. He sent them Ibn 
'Abbās, one of the most learned companions, who had a long intellectual debate with them. Following the debate, two thousand Kharijites who realised and admitted their mistakes joined the Muslim camps. (see the debates in al-San'ānī, 1983, 14: 157-160; and Ahmad, 2001, 5: 263). Others were inevitably fought. As time passed, owing to their eccentric views and practices, the Kharijites were eventually doomed to stagnation and marginalisation.

Imbued with confidence, Islam prides itself on the credibility and validity of its worldview and has no fear of the intrusion of alien ideas and thoughts which may be at odds with Muslim beliefs and doctrines. As things are easily recognisable vis-à-vis their opposites, Islam, with all that it stands for, when thoroughly studied and compared with counter thoughts, holds a firmer and stronger foundation, as long as it shares the platform for propagation.

-It is right that numerous Muslims were offended by Rushdie's Satanic Verses and therefore vehemently condemned it. It is equally right that their responses varied. While enraged Muslims burned the book demanding the death of the author, some writers and intellectuals defended Rushdie's position in the name of freedom of expression. The third party tried to distinguish between free speech and blasphemy. This variation was overlooked by a counter image, created and bolstered by the western media, an image of monolithic Muslim response. At best, very inadequate attention and respect were given to the fact that the Muslims' were deeply hurt and disrespected and those feeling were behind their wrath and outrage.

Fifth: Justice is first and foremost.

"O believers, be steadfast in your devotion to God, bearing witness to the truth in all equity. And never allow your hatred of any people to lead you away from justice. Be equitable that is nearer to godfearing." (The Qur'an, 5: 8). According to this verse, people in general and believers, in particular, are requested to act justly towards each other and never let hatred, whether justified or otherwise, be conducive to being unjust to anyone.

Kind treatment, fair dealings, and religious freedom accorded to peoples of other faiths and nations played a primary role in bringing people into Islam. History had witnessed that various minorities, belonging to diverse religious and ethnic backgrounds, enjoyed the privilege of practising their own faith. They were 
involved in amicable relationships with Muslims, having no fear of coercive conversion or oppressive administration. (See examples in Bakkour, 2011, 32-44).

Sixth: Honey catches more flies than vinegar.

Opinions presented in a courteous and civilised fashion is most likely to be accepted or adopted than those presented in an offensive manner, even if it is supported by solid evidence. God decrees, "Do not argue with the people of earlier revelations except in the most kindly manner." (The Qur'an, 5:8). Moreover, "Call people to the path of your Lord with wisdom and goodly exhortation, and argue with them in the most kindly manner." (The Qur'an, 16: 125).

Seventh: "Do not pursue that of which you have no knowledge. Man's ears, eyes and heart shall be called to account." ( The Qur'an, 17:36). One of its impressive characteristics is that Islam neither accepts assumptions nor permits anything to be based on suspicion or myth. Every theory, dogma, argument or even faith should be substantiated by concrete evidence and a solid foundation.

Shedding light on the excellent scientific method indicated in this verse, Sayyid Qutub wrote:

These few words establish a complete method for the human mind and heart, incorporating the scientific approach that humanity has begun to apply recently.... Making certain of every report, action or situation before passing a judgment concerning it is the essence of the Qur'anic approach. When hearts and minds faithfully follow this approach, there remains no room for superstition in the matters of faith, or for suspicion in legal affairs.... Scientific integrity which, in modern times, people unreservedly praise, is no more than the conscientious integrity which the Qur'an establishes as a requirement to be accounted for. (2008, 11:163).

Similarly, the Prophet (PBUH), in a number of authentic sayings, ordered Muslims not to get engaged into acts of lying, and to refrain from false assumptions in their reports. (Qutub, 2008, 11:163-164). 


\section{Conclusion}

Supporters of civilisational dialogues and peacebuilding are entrusted with a dual task: First, they need to take a firm stand against the rhetoric of pretentious writers, hate mongers and warmongers, such as Bernard Lewis and Samuel Huntington. Second, they can opt to educate others by means of historical precedents of positive interaction and cooperative relationship between Muslims and the West enabling bridges of present-day coexistence, mutual understanding and genuine partnership to be constructed.

\section{References}

Abou El Fadl, K. (2005). The Great Theft. New York: Harper SanFrancisco.

Ahsan, M.M. \& Kidwai, A.R. (Eds.). (1993). Sacrilege Versus Civility: Muslim Perspectives on the Satanic Verses Affair. Leicester: The Islamic Foundation.

Ibn al-Altheer, M. D. (1969). Jāmi` al-Usoul. Damascus: Maktabat al-Halwānī.

Ansari, Z. \& Esposito, J. (Eds.). (2001). Muslims and the West: Encounter and Dialogue. Islamabad: Islamic Research Institute; Washington: Center for Muslim-Christian Understanding.

Bashier, Z. (1990). Sun Shine at Madīnah. Leicester: The Islamic Foundation.

Bakkour, B. (2010). The Prophet Muhammad: The Perfect Example. Damascus: Al-Fatih Islamic Institute.

Bakkour, B. (2011). The Spread of Islam: Perceptions and Misperceptions. Damascus: Pioneers Publishing House, 2011. 
Baroudi, S. (2004). "The 2002Arab Human Development Report: Implications for Democracy, " Middle East Policy, 11, (1), 132-141.

Blum, W. (2000). Rogue State: A Guide to the World's Only Superpower. (USA: Common Courage Press.

Al-Bukhārī, M. (1987). Sahih Al-Bukhārī. Cairo: Dar al-Rayyan.

Al-Buti, M.S.R. (1978). Fiqh al-Seerah. Cairo: Islamic Da'wah Library.

Chossudovsky, M. (2005). America's “War on Terrorism. ” Canada: Global Research.

Clarke, J. (1997). Oriental Enlightenment: The Encounter between Asian and Western Thought. London and New York: Routledge.

Dekmejian, R. H. (2004). Multiple faces of Islam. in A. Jerichow \& J.BÆk Simonsen. (Eds), Islam in a Changing World: Europe and the Middle East. (Pp. 1-12). London and New York: Routledge Curzon.

Djalili, M. R. (1995). "dar al-harb” in John Esposito. Editor in Chief. The Oxford Encyclopedia of the Modern Islamic World. (1: 337-338). Oxford: Oxford University Press.

Al-Fayrouzabadi, M. D. (2005). Al-Qamous al-Muheet. Damascus: Mu'assasat al-Risalah.

Esposito, J. (1999). The Islamic Threat Myth or Reality? Oxford: Oxford University Press.

Glass, C. (2004) "Lewis of Arabia" Avaliable at $<$ http://www.thenation.com/doc/20040913/glass >.

Guillaume, A. (1990). The Life of Muhammad. Karachi, Oxford: Oxford University Press. 
Haddad, Y. Y. (1993). The 'New Enemy'? Islam and Islamists after the Cold War. in Phiyllis Bennis \& Michel Moushabeck (Eds). Altered States: A Reader in the New World order (pp. 83-94). New York: Olive Branch Press.

Haddad, Y. Y. (2000). "The Dynamics of Islamic Identity in North America." in Yvonne Haddad \& John Esposito, (Eds). Muslims on the Americanization path (pp. 19-46). New York: Oxford University Press.

Halliday, F. (2002). Islam and the Myth of Confrontation. (London $\&$ New York: L.B. Tauris).

Ibn Hanbal, A. (2001). Al-Musnad. Damascus: Dar al-Risalah. Hansen, Stig, et al, (Eds). (2009). The Borders of Islam: Exploring Huntington's Faultines, from Al-Andalus to the Virtual Ummah. London: Hurst \& Company.

Higham, N., \& Ryan, M. (2010). "Museum explores 'hidden history' of Muslim science.”. BBC News. Retrieved December 11 2010.

$<$ http://news.bbc.co.uk/2/hi/uk_news/8472111.stm>.

Huntington, S. (1993). The Clash of Civilizations? Foreign Affairs, $72(3), 22-49$.

Huntington, S. (1996). The Clash of Civilizations and the Remaking of World Order. New York: Simon \& Schuster.

Jerichow, A. (2004). Civilizations: Clash or Co-operation? in A. Jerichow and J.BÆk Simonsen. (Eds). Islam in a Changing World: Europe and the Middle East (Pp. 144-156.). London and New York: Routledge Curzon.

Lewis, B. (1990). "The Roots of Muslim Rage," Atlantic Monthly, Available at this website <http://www.sullivancounty.com/id3/lewis 2. htm>. 
Lockman, Z. (2004). Contending Visions of the Middle East. The History and Politics of Orientalism. Cambridge: Cambridge University Press.

Matlock, J. (2006). “Can Civilizations Clash?” Proceedings of the American Philosophical Society, 143 (3), 428-439.

Malik, I. (2006). Crescent Between Cross and Star Muslims and the West after 9/11. Oxford: Oxford University Press.

Svein, M. (2009). Bosnia-Religion and Identity. In Hansen, Stig Jarle, et al, (eds), The Borders of Islam: Exploring Samuel Huntington's Faultines, from Al-Andalus to the Virtual Ummah (Pp. 211-221). London: Hurst \& Company.

Al-Qushayrī, M. I. H.. (n.d). Sahih Muslim. Damascus: Al-Ghazālī. Al-Qaradāwī, Y. (2009). Fiqh al-Jihād. Cairo: Maktabat Wahbah.

Al-Qaradāwī, Y. (1994). Lawful and Prohibited in Islam, Trans. Kamal el-Helbawy, et al. Indianapolis, IN: American Trust Publications.

Qutb, S. (2008). In the Shade of the Qur'ān. Trans. M.A. Salahi and A.A. Shamis. Leicester, UK: Islamic Foundation.

Ramadan, T. (2005). To Be a European Muslim. Leicester: The Islamic Foundation.

Reid, B. (2009). Philippines- "Civilizational” or Colonial Border, In Hansen, Stig Jarle, et al, (eds), The Borders of Islam: Exploring Samuel Huntington's Faultlines, from Al-Andalus to the Virtual Ummah (Pp. 99-109). London: Hurst \& Company.

Said, E. (1997). Covering Islam. How the Media and the Experts determine How We See the Rest of the World. London: Vintage Books. 
Salahi, M.A. (2002). Muhammad: Man and Prophet: A Complete Study of the Life of the Prophet of Islam. Leicester, UK: Islamic Foundation.

\section{Al-San`ān̄̄, A. R. (1983). Al-Musannaf. Beirut: Al-Maktab Al- ISlami.}

Shaw, S. J. (1991). The Jews of the Ottoman Empire and the Turkish Republic, UK: Macmillan Press.

Al-Zyhayli, W. (1983). Āthār al-Harb fī al-Fiqh al-Islāmi. Damascus: Dar al-Fikr.

\section{Endnotes}

${ }^{i}$ The eminent jurist Abu Hanifah sees the observable security of the residents as a major parameter of the abode of Islam and of war; i.e. if Muslims enjoy security in a particular place, it is counted as an abode of Islam. Al-Zyhayli, Āthār alHarb fī al-Fiqh al-Islāmi. P. 172.

ii On the U.S hegemonic policies, one comes across substantial materials, like Lens, Sidney. The Forging of the American Empire. From the Revolution to Vietnam: A History of U.S Imperialism. (London: Pluto Press; Chicago: Haymarket Books, 2003); Michael Mandel, How America Gets away with Murder: Illegal Wars, Collateral Damage and Crimes against Humanity. (London: Pluto Press, 2004); Noam Chomsky, Rogue States: The Rule of Force in World Affairs. (London: Pluto Press, 2000).

iii A measure of capacity (3 kg. Approximately). Al-Fayrouzabadi, Al-Qamous alMuheet. (Damascus: Mu'assasat al-Risalah, 2005), p. 739.

${ }^{\text {iv }}$ For books highlighting a fruitful European interaction with Muslim scholarship, see Dorothee Metlitzki, The Matter of Araby in Medieval England. (New Haven: Yale University Press, 1977); Khalil I. Semaan, ed. Islam and the Medieval West: Aspects of Intercultural Relations. (Albany.N.y; State University of NewYork Press and, 1980); Maria Rosa, The Arabic Role in Medieval Literary History: A forgotten Heritage. (Philadelphia: University of Pennsylvania Press, 1987); J. Clarke, Oriental Enlightenment: The Encounter between Asian and Western Thought. (London and New York: Routledge, 1997); Paul Coles, The Ottoman Impact on Europe. (London: 1968); R.A. Jairazbhoy, Oriental Influences in Western Arts. (New York: 1965); J.T. Monroe, Islam and the Arabs in Spanish Scholarship. (Leiden: 1970). Salim al-Hassani, 1001 Inventions: Muslim Heritage in Our World. 2nd ed. (UK: Foundation for Science Technology and Civilization, 2007). 
${ }^{\mathrm{v}}$ Professor Salim al-Hassani said that during a seminar, (which I attended), on Islamic civilization at the Fatih Islamic Institite, in Damascus, in 2009.

${ }^{\text {vi }}$ On this affair with the heated debate it provoked, see M.M. Ahsan and A.R. Kidwai, eds. Sacrilege Versus Civility: Muslim Perspectives on the Satanic Verses Affair. (Leicester: The Islamic Foundation, 1993); Lisa Appignaneti and Sara Maitland, The Rushdie File (London: Fourth Estate, 1989); Malise Ruthven, A Satanic Affair; Salman Rushdie and the Rage of Islam (London: Hogarth Press, 1990); Daniel Pipes, The Rushdie affair: the novel, the Ayatollah, and the West. (USA: Transaction publishers, 2009); Jeremy Jennings, and Anthony KempWelch, eds. Intellectuals in Politics: from the Dreyfus affair to the Rushdie affair. (London: Routledge, 1997); Catherine Cundy, Salman Rushdie. (UK: Manchester University Press, 1996); Steve MacDonogh, ed. The Rushdie letters: freedom to speak, freedom to write. (UK: Brandon Book Publishers Ltd, 1993); Salman Rushdie, and Michael Reder, Conversations with Salman Rushdie. (USA: University Press of Mississippi, 2000); M. D. Fletcher, ed. Reading Rushdie: perspectives on the fiction of Salman Rushdie. (The Netherlands, 1994); Kenan Malik, From Fatwa to Jihad: The Rushdie Affair and Its Aftermath. (New York: Melville House, 2010) Tariq Moddod, "British Asian and Muslims and the Rushdie Affair," The Political Quarterly, 61, no. 2, pp.143-160 (1990); Bhikhu Parekh, "The Rushdie Affair: Research Agenda for Political Philosophy," Political Studies, 38, no. 4. Pp. 695-709 (1990); M.M. Slaughter, "The Salman Rushdie Affair: Apostasy Honor, and Freedom of speech," JSTOR, 79, no. 1 (1993); James Piscatori, "The Rushdie Affair and the Politics of Ambiguity," International Affairs, 66 (1990) pp. 767-89.

vii The original Satanic Verses, which gave their name to Rushdie's novel, were statements allegedly uttered by the Prophet as part of the Qur'anic revelation.

It was reported that the Prophet was reciting a newly revealed Qur'anic chapter (The Star). As he reached the following verses pertaining Quraysh's worshipped idols: Have you ever considered al-Lat and al-'Uzza, as well as Manat, the third, the other? [Qur'an, 53: 19-20] The Satan put in the Prophet's mouth the following words, "These are the sublime birds, whose intercession is to be hoped for." Having heard this unexpected praise for their idols, the idolaters in Makkah became supremely happy and delightful. When the Prophet completed the recitation of the Chapter, he prostrated himself, and all those present, Muslims and idolaters alike, also prostrated themselves. Not realizing what Satan did, the Prophet continued to recite new verses with the infiltrated words for days in prayer, until the Angel Gabriel came and corrected the Prophet. This story, although mentioned in earlier Muslim historical sources, was not reported by anyone who may be graded as an accurate reporter or reliable transmitter. Further, scholars, Muslims and non-Muslims have proven that the story is fallacious with no foundation at all. See a good treatment of this preposterous story in M.M. Ahsan "The 'Satanic' Verses and the Orientalists" Sacrilege Versus Civility, pp. 131-141. 